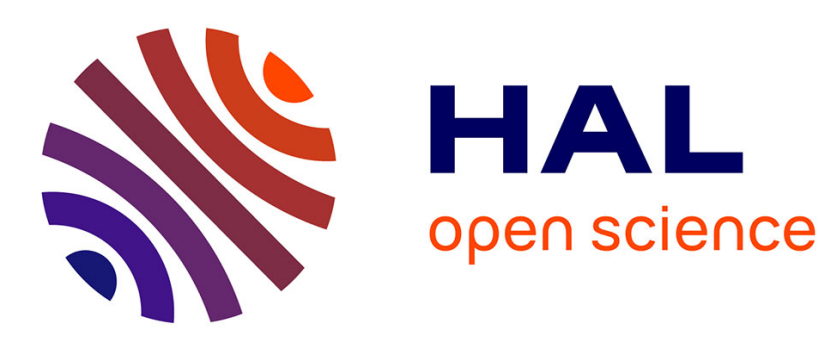

\title{
Concernee-Concern constructions
}

Mark van de Velde

\section{To cite this version:}

Mark van de Velde. Concernee-Concern constructions: a comparative study of external possession in the Bantu languages. Studies in Language, 2020, 44 (1), pp.70-94. 10.1075/sl.18059.vel . halshs02568048

\section{HAL Id: halshs-02568048 \\ https://shs.hal.science/halshs-02568048}

Submitted on 8 May 2020

HAL is a multi-disciplinary open access archive for the deposit and dissemination of scientific research documents, whether they are published or not. The documents may come from teaching and research institutions in France or abroad, or from public or private research centers.
L'archive ouverte pluridisciplinaire HAL, est destinée au dépôt et à la diffusion de documents scientifiques de niveau recherche, publiés ou non, émanant des établissements d'enseignement et de recherche français ou étrangers, des laboratoires publics ou privés. 


\title{
Concernee-Concern constructions: a comparative study of external possession in the Bantu languages
}

Mark Van de Velde (LLACAN - CNRS/INALCO)

mark.vandevelde@cnrs.fr

Prefinal version

Published as:

Van de Velde, Mark L.O. (2020) Concernee-Concern constructions: A comparative study of external possession in the Bantu languages. In: Studies in Language 44 (1): 70-94. doi: 10.1075/sl.18059.vel

\begin{abstract}
This paper provides an analysis of the phenomenon commonly known as external possession in the Bantu languages. On the basis of comparative data, I argue for a prototype approach to the intricate problem of determining the conditions of use of such constructions, which I rename Concernee-Concern constructions, introducing two new terms for the thematic roles involved. Situations can be expressed by means of Concernee-Concern construction if they correspond to the prototypical situation that involves somebody's body part being affected by an action, or if they show a family resemblance to this situation. I argue against the relevance of alienability. The paper also provides a formal typology of Concernee-Concern constructions in the Bantu languages.
\end{abstract}

\section{Introduction ${ }^{1}$}

\footnotetext{
${ }^{1}$ I wish to thank Denis Creissels, Dmitry Idiatov, Tatiana Nikitina, the audiences of the $23^{\text {rd }}$ Afrikanistentag in Hamburg and the SOS collègues seminar at LLACAN, and three anonymous reviewers for their useful comments. This work is part of the project LC2 "Areal phenomena in Northern sub-Saharan Africa" of the Labex EFL (program "Investissements d'Avenir" overseen by the French National Research Agency,
} 
Constructions of the type exemplified in (1a) are commonly known as external possession constructions (Payne \& Barshi 1999). They contain an argument that can alternatively be construed as the possessive modifier of an argument for which their verb subcategorises, as in (1b).

(1) Kinyarwanda (Davies 1997: 100, citing Kimenyi 1980)

a. umu-góre y-a-shokoj-e umu-gabo umu-satsi

1-woman $\mathrm{SM}_{1}$-PST-comb-FV 1-man 3-hair

'The woman combed the man's hair.'

lit. 'The woman combed the man the hair.'

b. umu-góre y-a-shokoj-e umusatsi w' w' $^{\prime}$ ûmu-gabo

1-woman $\mathrm{SM}_{1}$-PST-comb-FV 3-hair $\quad \mathrm{CON}_{3}=1$-man

'The woman combed the man's hair.'

These constructions are notoriously difficult to handle in what Taylor (2014) calls dictionary-and-grammar models of language, because they contain an extra-thematic argument that has all the formal characteristics of a nuclear argument. This argument is extra-thematic in the sense that it is not subcategorised for by the verb, nor is it licensed by an adposition (Shibatani 1994). In the Bantu languages where it is sometimes accompanied by a valence-increasing applicative suffix on the verb, this suffix by itself does not license an external possessor role. There are always other conditions that need to be met, which will be discussed in Sections 3 and 4 .

Much of the literature on external possession constructions in individual Bantu languages has been concerned with finding the best way to deal with them in one or the other formal model of grammar. This has had the advantage that authors have been systematic in exploring the aspects of external possession constructions that

reference: ANR-10-LABX-0083). The following abbreviations are used in the glosses: $1,2,3, \ldots$ marker of noun class 1, 2, 3... (subscript if marking class agreement); APPL applicative; CAUS causative; CON connective ( $\approx$ genitive); COP copula; DEM demonstrative; DTP definite tone pattern; FPST far past; FUT future; FV Final Vowel (a TAM suffix); INC inceptive; LOC locative; OM object marker; POSS possessive pronoun; PP pronominal prefix (a paradigm of agreement prefixes); PRF perfect; PRO personal pronoun; PRS present; PST past; REL relativiser or relative verb form; RPST recent past; SG singular; SM subject marker; STAT stative; TAM tense-aspect-modality. 
were of direct interest to them. A relative disadvantage is that there is a certain poverty in (contextualised) data. For instance, the same examples tend to be recycled in the papers on external possession in Swahili, viz. Hinnebusch \& Kirsner (1980), Scotton (1981) and Keach \& Rochemont (1992). Other published studies of external possession in the Bantu languages are Voeltz (1976) on Sotho, Hyman (1977) on Haya (republished as (Hyman 1996)), Bickford (1986), Davies (1997) and Gerdts (1999) on Kinyarwanda, Simango (2007) on Chichewa and Henderson (2014) on Chimwiini.

This paper is the first comparative study of the phenomenon in the Bantu languages. Its main finding is that external possession is a family of constructions used to express a set of situations with a prototype structure, i.e. one that has a very specific situation type at its core, as well as departures from that core based on family resemblances. The paper is at times programmatic, because it has to rely on a limited set of data. Particularly lacking are studies of external possession based on a large corpus of spontaneous speech. In Section 2, I will introduce a terminological innovation that makes it easier to analyse external possession constructions and to typologise their formal variation, viz. the construction-specific roles of Concernee and Concern. The construction itself will be renamed Concernee-Concern construction. Section 3 argues against the oft-invoked relevance of the notion of alienability. Many authors have noticed that body parts are prototypical possessees in external possession constructions, but appear to have been dissatisfied with the low level of generalisation of this observation. Consequently, body parts were replaced by the more abstract but inaccurate inalienably possessed. The special significance of body parts will be highlighted in Section 4, where it is shown that they are an ingredient of the situation type prototypically expressed by a Concernee-Concern construction, and that some languages use different Concernee-Concern constructions depending on whether they are used to express a prototypical situation or not. Section 5 further elaborates the formal typology of Concernee-Concern constructions in the Bantu languages. Finally, Section 6 looks at some north-western Bantu languages whose 
grammars allow utterances similar to that in (1a) without needing a specific Concernee-Concern construction.

For the purpose of this comparative study, I will define Concernee-Concern constructions as constructions used to highlight the fact that an event is of concern to an individual (the Concernee) that has a privileged relation to a thematic argument of the verb (the Concern). They do so by expressing this individual as a nuclear argument. The effect of the event on the Concern is backgrounded, which tends to result in reduced behavioural potential of the syntactic relation onto which it is mapped.

\section{Two construction-specific roles: Concernee and Concern}

The goal of this short section is to address the lack of generally agreed upon terminology needed for discussing and typologising "external possession" constructions. I will do so by proposing new terms for the roles that correspond to the possessor and the possessee in the alternative adnominal possession construction. The suggestion to assign a thematic role to "external possessors" has been made several times in the general literature, seemingly independently. It tends to be called Affectee (Gerdts 1999; Hole 2006; Schrock 2007; Seržant 2016), because affectedness of the extra-thematic argument is often invoked as a necessary condition for Concernee-Concern constructions to be possible. However, characterising this role as being affected is probably too restrictive. There are many examples in which the relevant participant is not clearly affected by the event, such as the child in (2b) from Haya. The lack of affectedness of the child in the situation reported in (2) probably explains why this situation can easily be expressed by means of adnominal possession, as in (2a). According to Hyman, there are restrictions on the use of the Concernee-Concern construction in (2b). The child has to be present (versus pictured) and alive in order to be somehow concerned by the event, but she does not have to be affected by it. 
(2) Haya (Hyman 1977: 105)

a. y-kà-bón' ómù-kònò gw' =ómw-áànà

$\mathrm{SM}_{1 \mathrm{sg}}$-FPST-see 3 -arm $\quad \mathrm{CON}_{3}=1$-child

'I saw the child's arm.'

b. y-kà-bón’ ómw-áán' ómù-kônò

$\mathrm{SM}_{1 \mathrm{sg}}$-FPST-see 1-child 3-arm

'I saw the child's arm.' ${ }^{2}$

As pointed out to me by Denis Creissels, the notion of affectedness is also too broad, because it is equally used with respect to the Patient role in analyses of differential object marking, for instance. From this point of view, affectedness is mostly relevant for the Possessee participant, which I call Concern, rather than for the External Possessor/Concernee. On top of avoiding such potential misunderstandings, the new term Concernee has the advantage of being transparently paired with the term Concern, showing that the notion is a construction-specific one and that the existence of a Concernee role presupposes that of a Concern role, and vice versa.

What has been especially lacking so far is a transparent and practical term for the other participant, sometimes referred to as the (external) possessee or the host (Keach \& Rochemont 1992). Since it is a thematic participant in the event that is of concern to the Concernee, it can simply be called Concern, short for the more accurate but more cumbersome Object, Source or Locus of Concern. As has been said, the motivation for introducing these two terms is mainly practical: they make it easier to describe the rich formal variation that can be found in Concernee-Concern constructions.

\footnotetext{
${ }^{2}$ Regarding the contexts in which (2b) can be used instead of (2a), Hyman does not mention anything that could point to greater affectedness of the child. One possible context he mentions is that the subject was not supposed to see the child's arm, and this could be seen as a source of concern for the child. Somewhat surprisingly, another possible context involves contrastive focus on the arm. As I will argue below, the Concernee-Concern construction in $(2 b)$ is possible as an alternative to (2a) thanks to the family resemblance between the situation reported in (2) and the type of situation prototypically expressed by means of a Concernee-Concern construction.
} 


\section{Body parts are relevant, not (in)alienability}

Much of the literature on external possession constructions is concerned with determining the circumstances under which they can be used. Typically, very few instances of adnominal possession can be alternatively expressed by means of a Concernee-Concern construction. As seen in (3a), somebody whose chair is broken cannot normally take the Concernee role and be expressed as an argument of the verb 'break' in Swahili, versus a person whose leg was broken (3b).

(3) Swahili (Keach \& Rochemont 1992: 88)

a. *ni-li-m-vunja Juma ki-ti $\mathrm{SM}_{1 \mathrm{sG}}$-PST-OM -break 1.Juma 7-chair Intended: 'I broke Juma's chair.'

b. ni-li-m-vunja Juma m-guu

$$
\begin{array}{rrl}
\mathrm{SM}_{1 \mathrm{sG}}-\text { PST} \mathrm{OM}_{1} \text {-break } & \text { 1.Juma } & \text { 3-leg } \\
\text { CONCERNEE } & \text { CONCERN }
\end{array}
$$

'I broke Juma's leg.'

Authors such as Hyman (1977) have correctly pointed out that body parts are typically construed as Concerns in Concernee-Concern constructions (here reformulated in my terminology). This observation has been widely reinterpreted to mean that external possession is an alternative way of encoding inalienable possession as opposed to alienable possession (for the Bantu languages e.g. in Keach \& Rochemont 1992; Henderson 2014). The terms alienable and inalienable are used as labels for alternative encodings of adnominal possession. Depending on the language, the choice between these alternative encodings is either lexically determined (Nichols \& Bickel 2013) or predominantly semantically determined. The Bantu languages can be argued to have an alienability distinction of the former, lexical type, because the construction used to modify certain kin terms by means of a pronominal or proper name possessor differs from that used to modify other nouns (Van de Velde, to appear). Example (4) shows the distinction in Lunda. The noun for 'grandchild' is alienably possessed. Like most other nouns it is modified by a possessive pronoun that consists of a connective relator $P P$ - $a$ - and a pronominal stem 
(4a). ${ }^{3}$ The word for 'sister', in contrast, is inalienably possessed. The modifying possessive pronoun in (4b) consists of a stem only, lacking the connective relator.

(4) Lunda (Kawasha 2003: 113, 115)

a. mwizukulu windi

mu-izukulu wu-a-indi

1-grandchild $\quad \mathrm{PP}_{1}$-CON-POSS.3SG

'his/her grandchild'

b. muhelindi

mu-hela $=$ indi

1 -sister $=$ POSs.3sG

'his sister'

Crucially, the kinship terms that are inalienably possessed in the Bantu languages are rarely construed as Concerns. In contrast, body part terms, the most typical Concerns, are not inalienably possessed in the Bantu languages. ${ }^{4}$ Contrary to what its title suggests, Voeltz' Inalienable possession in Sotho (Voeltz 1976) makes a similar case. On semantic grounds, Voeltz rejects the relevance of (in)alienability and claims that Concernee-Concern constructions are possible in Sotho if there is a part-whole relation between the Concernee (the whole) and the Concern (the part).

\section{The prototypical situation}

Voeltz' suggestion that Concernee-Concern constructions are possible in Sotho as soon as a part-whole relation holds between the Concern and the Concernee does certainly not cover all instances found in the Eastern Bantu languages, as illustrated by the example in (5), which does not involve a part-whole relation between both roles. Other, even clearer examples are (10b), (15a), (26a) and (29a).

\footnotetext{
${ }^{3}$ PP is short for Pronominal Prefix, a paradigm of agreement markers. In this construction, the PP marks agreement in class with the head noun.

${ }^{4}$ The only clear example known to me of a Bantu language in which body parts are inalienably possessed is Bila, a language that is in close contact with Eastern Sudanic and Ubangian languages (Kutsch Lojenga 2003).
} 
(5) Swahili (Keach \& Rochemont 1992)

$\begin{array}{llll}\text { m-ganga } & \text { a-li-mw-ondoa } & \text { Juma } & \text { risasi } \\ \text { 1-doctor } & \mathrm{SM}_{1}-\mathrm{PST}_{-} \mathrm{OM}_{1} \text {-remove } & \text { 1.Juma } & \text { 9.bullet } \\ & & & \\ & & \text { CONCERNEE } & \text { CONCERN }\end{array}$

'The doctor removed the bullet from Juma.'

Hyman (1977: 104) points out three preconditions for Concernee-Concern constructions in Haya, viz. (i) the possessed noun is a body part, (ii) the verb is an action verb that is likely to affect the Concernee and (iii) the Concernee is high on the referentiality hierarchy. He also cites many examples in which at least one of these preconditions is not met, stating that these are only acceptable in marked contexts and/or with specific interpretations. The utterance in (6a), for instance, is fine if and only if the Concernee 'child' was wearing the shirt when the speaker tore it. If not, the adnominal possessive construction in (6b) has to be used.

(6) Haya (Hyman 1977: 105)

a. y-ka-teemul' ómw-áán' é-shaati

$$
\begin{array}{lll}
\mathrm{SM}_{1 \mathrm{SG}} \text {-FPST-tear } & \text { 1-child } & \text { 9-shirt } \\
& \text { CONCERNEE } & \text { CONCERN }
\end{array}
$$

'I tore the shirt of/off the child.'

b. y-ka-teemul' é-shaati y' = ómwáana

$\mathrm{SM}_{1 \mathrm{SG}}$-FPST-tear 9-shirt $\mathrm{CON}_{9}=$ child

'I tore the shirt of the child.'

In the remainder of this section, I will argue for a change in perspective towards a holistic approach in which the characteristics enumerated by Hyman (1977) and others are not seen as individual preconditions under which Concernee-Concern constructions are possible, but rather as elements that characterise the prototypical situation type expressed by Concernee-Concern constructions. A characterisation of the prototypical Concernee-Concern situation is provided in (7), and an example in (8).

(7) THE PROTOTYPICAL CONCERNEE-CONCERN SITUATION 
In the prototypical Concernee-Concern situation, a familiar Concernee is affected by a change of state brought about in one of their body parts.

(8) Lunda (Kawasha 2003: 252)

Mukwenzi wakotoka kánsi mwendu

Mu-kwenzi wu-a-kotok-a ka-ánsi mu-endu

1-young.mansM ${ }_{1}$-PST-break-FV 12-child 3-leg

CONCERNEE CONCERN

'The young man broke the child's leg.'

Departures from prototypical instances must have some family resemblance with them and can be more or less dramatic depending on the language, the speaker and the richness of the context. Ideally, the prototype structure of Concernee-Concern constructions should be studied in large corpora of individual languages. From an onomasiological point of view, I would expect to find that the more a situation is similar to the prototypical situation, the more likely it is to be expressed by means of a Concernee-Concern construction. From a semasiological point of view, I would expect that the great majority of the attested Concernee-Concern constructions are used to express situations that are highly similar to the prototypical situation.

A preliminary confirmation of the latter expectation can be found in a small corpus study on Swahili (Kyei-Mensah 1998). Kyei-Mensah looked up all instances of Concernee-Concern constructions in a corpus of four novels. The examples of what she calls transitive affective constructions contain twenty-five different nouns used to express the Concern role. Eleven of these are body parts, with mkono 'hand' having by far the highest token frequency. The others are straightforward metonymical extensions of body parts: either items of clothing (5 types) or items that reside in or are produced by the body, such as mental states ('insanity', 'fear'), 'soul', 'blood' and 'breath' (9 types) (Kyei-Mensah 1998: 121). She groups the attested types of events into three categories, viz. grooming \& caring (e.g. 'massage', 'close', 'remove'; 16 tokens), grappling (e.g. 'break', 'throttle'; 6 tokens) and grasping (e.g. 'grasp', 'hold'; 21 tokens) (Kyei-Mensah 1998: 122). Grasping events could be seen as a minor departure from the prototypical event type, in that they do not normally bring about 
a change of state. However, they are similar in being highly agentive activities involving physical contact.

In the absence of more and larger corpus studies, my evidence for a prototype approach is mainly comparative and based on the examples provided in the literature. There are three types of evidence for recognising that situations in which a salient person is affected by an action on their body part stand out as those prototypically expressed by a Concernee-Concern construction: OMNIPRESENCE, OBLIGATORINESS and LACK OF MARKING. As for omnipresence, according to the available descriptions, the prototypical situation can be expressed by means of a ConcerneeConcern construction in every language that has such a construction. In other words, if a Bantu language has a Concernee-Concern construction, it can be used to express actions that have an effect on somebody's body part.

Second, in an unknown number of Bantu languages including Haya, the use of a Concernee-Concern construction is OBLIGATORY for expressing the type of situation for which it is prototypically used. When someone is affected by an action on their body part, this person HAS TO be construed as a Concernee and cannot be alternatively expressed as an adnominal possessor. Thus, example (9) would only be acceptable in the highly unlikely event that the child were in possession of somebody else's detached arm.

(9) Haya (Hyman 1977: 101)

'n-ka-hénd' ómu-kono gw' = ómw-áana

$\mathrm{SM}_{1 \mathrm{GG}}$-FPST-break 3-arm $\quad \mathrm{CON}_{3}=1$-child

'I broke the (detached) arm of the child.'

It is my impression that utterances like (9) are hardly acceptable in any Bantu language, even if this has not been stated as categorically as for Haya.

The third type of evidence for the existence of a prototypical situation type is lack of formal marking in Concernee-Concern constructions used to express the prototypical situation. Several Bantu languages have two types of Concernee-Concern construction that are distinguished by the presence versus absence of an applicative 
suffix on the verb. In these languages, no applicative suffix can be used when the Concern is an affected body part, whereas in other circumstances the use of the applicative may be either optional or obligatory. Examples of such languages can be found throughout the Bantu domain and include Orungu in the North-West (10), Kinyarwanda in the Centre and Tswana in the South (11). The a-examples in (10-11) involve a body part and lack an applicative suffix on the verb, whereas the bexamples, which do not have a body part Concern, have an applicativised verb.

(10) Orungu (Odette Ambouroue p.c.)

a. ogânga ayingí óywana ółgó

ò-gâygà à-à-yìng-1́ ònw-ânà ó-gò

1-healer.DTP SM$_{1}$-FPST-treat-FPST 1-child.DTP 3-arm.DTP CONCERNEE CONCERN

'The healer treated the child's arm.'

b. awáwวygíní ółĐwánto mbółm(i) (íyc)

$\begin{array}{llll}\text { àó-à-wòng-in-í } & \text { ó }^{\ddagger} \text { ww-ántò } & \text { m-bômì } & (\mathrm{y}-\grave{\varepsilon}) \\ \mathrm{SM}_{2 \mathrm{SG}} \text {-FPST-take-APPL-FPST } & \text { 1-woman.DTP } & \text { 9-calabash.DTP } & \text { (IX-POSS) } \\ & \text { CONCERNEE } & \text { CONCERN } & \end{array}$

'You took the woman's calabash.'

(11) Tswana (Creissels 2006: 108)

a. Ngw-ana o tlaa go gat-a le-tsogo

1-child $\mathrm{SM}_{1}$ FUT $\mathrm{OM}_{2 \mathrm{SG}}$ crush-FV 5-hand

$$
\text { CONCERNEE CONCERN }
$$

'The child will crush your hand.'

b. Ngwana o tlaa go j-el-a dinawa

$$
\begin{aligned}
& \text { 1-child } \mathrm{SM}_{1} \text { FUT } \mathrm{OM}_{2 \mathrm{SG}} \text { eat-APPL-FV 8/10.bean } \\
& \text { CONCERNEE CONCERN }
\end{aligned}
$$

'The child will eat your beans.'

I will use the term nuclear Concernee for Concernees that are not accompanied by an applicative suffix on the verb in such languages, and applied Concernee for the other cases. Note that in languages that have both, the use of the unmarked construction 
(i.e. without an applicative suffix) is not necessarily restricted to the expression of the prototypical situation type. In Orungu, it is used whenever the Concern is a body part, and in Kinyarwanda it is also used when the Concernee is affected by an action of taking/stealing (Kimenyi 1980: 97).

Before moving on to a typology of the formal variation found among ConcerneeConcern constructions in the Bantu languages, one more parameter of the conditioning of these constructions has to be mentioned. It has been alluded to in the definition proposed at the end of the introductory section, viz. that the Concern has to correspond to a thematic argument. Although all examples of Bantu Concernee-Concern constructions that I have found in the literature respect this condition, it is nowhere explicitly mentioned in the Bantuist literature, so that this remains to be verified. It is explicitly mentioned in Schaefer's (1995: 489) analysis of external possession in the Edoid language Emai. According to Schaefer, (12a) is possible because the locative Concern is subcategorised for by the verb 'be somewhere'. In contrast, (12b) is ungrammatical, because the locative is an adjunct.

(12) Emai (Schaefer 1995: 489)

a. évbii ríi ojé vbí úkpun palm_oil be king LOC cloth CONCERNEE CONCERN

'Palm oil is on the king's cloth.'

lit. 'Palm oil is the king on the cloth.'

b. *éli ikposo gbé ójé vbí íwe the women dance king LOC house intended: 'The women danced at the king's house.'

\section{Formal variation in Bantu Concernee-Concern constructions}

We have seen that Concernee-Concern constructions that express prototypical situations can differ formally from their non-prototypical counterparts in the absence versus presence of an applicative suffix on the verb. This section further elaborates 
the formal typology of Concernee-Concern constructions in the Bantu languages. We will start by taking up the presence of an applicative suffix again (5.1) and then look at the different ways in which the Concernee and the Concern can be mapped onto grammatical relations (5.2 and 5.3). The section concludes with notes on two other parameters of variation, viz. the presence of possessive pronouns that are coreferential with the Concernee (5.4), and recursivity (5.5).

\subsection{Presence or absence of an applicative suffix}

With respect to the presence of an applicative suffix in Concernee-Concern constructions, typologising languages leads to an interesting generalisation: no language uses the applicative suffix in all Concernee-Concern constructions. More specifically, I found no Bantu languages in which the Concernee-Concern construction that is used to express the prototypical situation type involves an applicative suffix. This is shown in Table 1.

\begin{tabular}{|l|c|c|}
\hline & + prototypical situation & - prototypical situation \\
\hline$(+)$ APP & & Orungu, Tswana, Kinyarwanda \\
\hline -APP & $\begin{array}{c}\text { Haya, Swahili, Chimwiini, } \\
\text { Chichewa, Orungu, Tswana, } \\
\text { Kinyarwanda }\end{array}$ & $\begin{array}{c}\text { Haya, Swahili, Chimwiini, } \\
\text { Chichewa }\end{array}$ \\
\hline
\end{tabular}

Table 1: Presence or absence of an applicative suffix

In the languages that have both applied and unapplied Concernee-Concern constructions, the use of the applicative suffix appears to be optional in the applied construction, marked by the brackets around the + in Table 1 . This generalisation is based on examples found in the literature which lack an applicative suffix where one is expected, such as (31). Depending on the language, optional may mean that other conditions are relevant than the mere presence of a Concernee.

\subsection{Mapping of the Concernee and Concern roles onto object relations}

In the absence of case marking, syntactic relations in the Bantu languages are characterized in terms of their order and their behavioural potential, i.e. whether 
they require, allow or disallow indexing on the verb; whether they can be the subject of a corresponding passive clause; or whether they are accessible to relativisation. In much of the literature, the term (direct) object is reserved for those grammatical relations that are postverbal, that can be indexed on the verb and that are accessible to passivisation and relativisation. The problem with such so-called object diagnostics is that they have low crosslinguistic operationality. Many northwestern Bantu languages do not have verbal object prefixes, for instance. Moreover, these criteria often do not align, because the exact formal behaviour of argument roles can depend on the referential properties of arguments and on the construction in which they appear. For the comparative purposes of this paper, I will use the term object to mean any unmarked NP that is not the subject.

In terms of constituent order, the Concernee always precedes the Concern when both are postverbal. If a nuclear Concernee is accompanied by an applied Beneficiary, the order is Beneficiary - Concernee - Concern (13).

(13) Swahili (Keach \& Rochemont 1992: 94)

$$
\begin{array}{llll}
\text { ni-li-m-chan-i-a } & \text { Juma } & \text { wa-toto } & \text { nywele } \\
\mathrm{SM}_{1 \mathrm{SG}}-\mathrm{PST}-\mathrm{OM}_{1} \text {-comb-APPL-FV } & \text { 1.Juma } & \text { 2-children } & \text { 10.hair } \\
& \text { BENEFICIARY } & \text { CONCERNEE } & \text { CONCERN }
\end{array}
$$

'I combed the children's hair for Juma.'

Likewise, when a nuclear and an applied Concernee-Concern construction are combined into one utterance in Kinyarwanda, the applied Concernee precedes the nuclear Concernee (14b).

(14) Kinyarwanda (Kimenyi 1980: 99)

a. umu-gabo y-a-vun-nye uku-ruguk'= úúmw-áana w'= ûmu-góre 1-man $\quad \mathrm{SM}_{1}$-PST-break-FV 15-leg $\mathrm{CON}_{15}=1$-child $\mathrm{CON}_{1}=1$-woman 'The man broke the leg of the child of the woman.' 

b. umu-gabo y-a-vun-i-ye
umu-góre úmw-áana uku-rugu
1-man
$\mathrm{SM}_{1}$-PST-break-APP-FV
1-woman
1-child
15-leg
CONCERNEE
CONCERN
(applied)
CONCERNEE CONCERN (nuclear)

'The man broke the leg of the child of the woman.'

The object relation used to express a nuclear Concernee has the same behavioural potential as that expressing the Recipient in a ditransitive give-clause: it can do everything. ${ }^{5}$ Applied Concernees have the same behavioural potential as applied Beneficiaries. In some languages, this implies some restrictions in behavioural potential. For instance, applied objects are not accessible to relativisation in Chichewa, according to Simango (2007).

(15) Chichewa (Simango 2007: 929, 937)
a. Tadala a-na-thyol-er-a
mw-ana ndodo
1.Tadala $\mathrm{SM}_{1}$-PST-break-APPL-FV 1-child 9.stick
CONCERNEE/ CONCERN/
BENEFICIARY PATIENT

'Tadala broke the child's stick' or: 'Tadala broke a stick for the child'

b. *Uyu ndi mw-ana amene Tadala a-na-thyol-er-a ndodo

DEM COP 1-child REL 1.Tadala SM $\mathrm{SM}_{1}$-PST-break-APPL-FV 9.stick

Intended: 'This is the child for whom Tadala broke the stick.' or 'This is the child whose stick Tadala broke.'

We now turn to the object relation used to express the Concern. The examples provided in Kawasha (2008) suggest that in Luvale the Concern has the same behavioural potential as the secondary object in a construction involving a ditransitive verb. Like other secondary objects, the Concern can be indexed on the verb by means of an enclitic if the primary object is indexed on the verb too. Example (16) shows this with a left dislocated Concern object.

\footnotetext{
${ }^{5}$ Except when an applied object is present as well, exemplified in (14b) and discussed below.
} 
(16) Luvale (Kawasha 2008: 41)

$\begin{array}{llll}\text { vy-uma } & \text { vyé-ényi } & \text { a-na-mu-támbul-á-vyo } & \text { mw-ána } \\ \text { 8-thing } & \text { 8-POSS } & \text { SM }_{2} \text {-TAM-OM } & \text {-take-FV-OM } \\ & & & \text { 1-child } \\ \text { CONCERN } & & \text { CONCERNEE }\end{array}$

'They have taken the child's things.'

However, it is much more common to find that the Concern object has a strongly reduced behavioural potential vis-à-vis comparable object relations, such as that used to express the Theme in ditransitive give-clauses or the Patient in double object constructions that contain an applied Beneficiary. Thus, in Zulu, either object in a double object construction can be indexed on the verb, except for the Concern in a Concernee-Concern construction (Zeller 2012). The same is true in Haya, where additionally the Concern is not accessible to passivisation (Hyman 1977). The Concern role is accessible to relativisation in Swahili (17), but not in applied Concernee-Concern constructions in Kinyarwanda (18), where the Concern is mapped onto an object with fully reduced behavioural potential.

(17) Swahili (Keach \& Rochemont 1992: 84)

mi-guu a-li-yo-m-funika m-toto

4-legs $\mathrm{SM}_{1}$-PST-REL 4 -OM ${ }_{1}$-cover 1-child

CONCERN CONCERNEE

'the child's legs which she covered'

(18) Kinyarwanda (Davies 1997: 92)

*ibí-ryo in-gurube z-aa-ri-ír-iye ábá-ana

8-food 10-pigs $\quad \mathrm{SM}_{10}$-PST-eat-APP-FV 2-children

Intended: 'the food that the pigs ate of the children'

In contrast, the Concern is mapped onto an object relation with nearly full behavioural potential in nuclear Concernee-Concern constructions in Kinyarwanda. This is shown in (19b), where the Concern is construed as the subject of a passive 
clause, in (19c), where it is indexed on the verb by means of the object prefix wu-, and in (19d), where it is clefted. ${ }^{6}$

(19) Kinyarwanda (Kimenyi 1980: 104)

a. umu-góre y-a-shokoj-e

umu-gabo umu-satsi

1-woman SM $_{1}$-PST-comb-FV 1-man 3-hair

CONCERNEE CONCERN

'The woman combed the man's hair.'

b. umu-satsi w-a-shokoj-w-e

$$
\text { umu-gabo n' = ûmu-góre }
$$

3-hair

$\mathrm{SM}_{3}$-PST-comb-PASS-FV

1-man

by $=1$-woman

CONCERN

CONCERNEE

'The man's hair was combed by the woman.'

c. umu-góre y-a-wu-shokoj-e umu-gabo

1-woman SM $_{1}$-PST-it-comb-FV 1-man

CONCERN CONCERNEE

lit. 'The woman combed it the man.'

d. n’ uumu-satsi umu-góre y-a-shókoj-e umu-gabo
COP 3-hair
1-woman SM $_{1}$-PST-REL.comb-FV 1-man
CONCERN
CONCERNEE

'It's the hair that the woman combed of the man.'

Note that in Kinyarwanda Concernee-Concern constructions, taking the behavioural potential of grammatical relations as diagnostics for their object status would lead to the paradoxical conclusion that the presence of the usually valency-increasing applicative suffix removes one object relation from the clause.

The behavioural potential of the object relation to which the Concern is mapped in three Bantu languages is summarised in Table 2.

\footnotetext{
${ }^{6}$ There is some confusion in the literature about whether nuclear Concerns are accessible to relativisation in Kinyarwanda. Davies (Davies 1997: 100), citing Kimenyi (1980) and personal correspondance with Kimenyi, claims that they are. Kimenyi (1980: 103) writes about the example in (19) that "the word 'hair', because it is an inalienable possession, can still be passivized, incorporated, relativized, clefted, and pseudo-clefted after promotion of the possessor NP to DO" (DO = Direct Object). But on the following page, he states that "relativization never applies to inalienable possessions."
} 


\begin{tabular}{|l|c|c|c|c|}
\hline & Haya & Swahili & Kinyarwanda applied & Kinyarwanda nuclear \\
\hline indexed on V & - & - & - & + \\
\hline passivisable & - & - & - & + \\
\hline relativisable & $?$ & + & - & $?$ \\
\hline
\end{tabular}

Table 2: The behavioural potential of the Concern object

The facts summarised in Table 2 can be accounted for when we look at the behavioural potential of the nuclear and applied Concernee in the Kinyarwanda example in (14b), repeated here as (20).

(20) Kinyarwanda (Davies 1997: 103, citing Kimenyi 1980)

$$
\begin{aligned}
& \text { umu-gabo y-a-vun-i-ye umu-góre úmw-áana uku-rugu } \\
& \text { 1-man } \quad \mathrm{SM}_{1} \text {-PST-break-APP-FV 1-woman 1-child 15-leg } \\
& \text { CONCERNEE CONCERN (applied) } \\
& \text { CONCERNEE CONCERN (nuclear) }
\end{aligned}
$$

'The man broke the leg of the child of the woman.'

In this construction, the nuclear Concernee object (here 'child') has the same reduced behavioural potential as the Concern in the applied construction. It is not accessible to passivisation (21a) and it cannot be indexed on the verb (22a). The applied Concernee is here the only object role with full behavioural potential (21b$22 b)$.

(21) Kinyarwanda (Davies 1997: 104, citing Kimenyi 1980)

a. umw-áana y-a-vun-i-w-e umu-góre uku-guru n'=ûmu-gabo 1-child $\quad \mathrm{SM}_{1}$-PST-break-APP-PASS-FV 1-woman 15-leg by=1-man *'The woman's child was broken her leg by the man.' (okay as 'The child's woman was broken her leg by the man.')

b. umu-góre y-a-vun-i-w-e úmw-áana oku-guru n'=ûmu-gabo 1-woman SM $_{1}$-PST-break-APP-PASS-FV 1-child 15-leg by=1-man 'The woman was broken her child's leg by the man.' 
a. umu-gabo y-a-mu-vun-i-ye umu-góre ukug-uru

1-man $\quad \mathrm{SM}_{1}$-PST-her-break-APP-FV 1-woman 15-leg

*'The man broke her (= the woman's child's) legs.'

(okay as 'The man broke her (= the child's) woman's leg.')

b. umu-gabo y-a-mu-vun-i-ye úmw-áana ukuguru

1-man $\quad$ SM $_{1}$-PST-her-break-APP-FV 1-child 15-leg

'The man broke her child's leg.'

This shows that a reduced behavioural potential may not be an inherent characteristic of Concern objects per se, but rather a consequence of the presence of a highly salient, strongly foregrounded Concernee role. The limited syntactic possibilities of other objects in the presence of an (applied) Concernee could mirror their relative backgrounding. ${ }^{7}$

\subsection{The Concern or Concernee is mapped onto the subject relation}

The previous section looked at constructions in which the Concernee and the Concern are both mapped onto an object relation. With intransitive verbs, either can end up as the subject too. Examples of this can be found in the East (e.g. Chimwiini) and the Northwest (e.g. Orungu). When the Concern is the subject, the Concernee is in postverbal object position and vice versa. When the Concernee is mapped onto an object relation, it has the full behavioural potential of objects. Object Concerns, in contrast, have a reduced behavioural potential. In Chimwiini, this can be seen in the inability of the Concern to be indexed on the verb (23), whereas the Concernee object in (24b) does trigger indexation. This is not only due to the fact that the Concern is inanimate, because inanimate Patient objects can optionally be indexed on the verb (25).

\footnotetext{
${ }^{7}$ According to an alternative analysis, the behavioural potential of 'child' in (20) could be said to be due to its status of Concern in the applied construction, rather that to its status of Concernee in the nuclear construction.
} 
(23) a. maana $\varnothing$-fur-ile miimba

1.child $\mathrm{SM}_{1}$-Swell-PST 9.stomach

CONCERNEE CONCERN

'The child's stomach swelled.'

b. *maana $\varnothing$-i-fur-ile (miimba)

1.child $\mathrm{SM}_{1}-\mathrm{OM}_{9}$-swell-PST 9.stomach

Intended: 'The child's stomach swelled.'

(24) Chimwiini (Henderson 2014: 302-303)

a. maana $\varnothing$-vund-ish-ile kuulu

1.child $\mathrm{SM}_{1}$-break-STAT-PST 9.leg

CONCERNEE CONCERN

'The child's leg is broken.'

b. kuulu i-m-vund-ish-ile maana

9.leg $\mathrm{SM}_{9}-\mathrm{OM}_{1}$-break-STAT-PST 1.child

CONCERN CONCERNEE

'The child's leg is broken.'

(25) xati, Muusa $\varnothing$-i-pelesh-ele

9.letter Musa $\quad \mathrm{SM}_{1}-\mathrm{OM}_{9}$-send-PST

'The letter, Musa sent it.'

In Orungu, the mapping of the Concernee and Concern roles on the subject and object relations in constructions with intransitive verbs appears to be conditioned by the referential properties of the Concernee. If it is human, it tends to be mapped on the object relation (26a-b), otherwise on the subject relation (26c). Again, there is a constructional difference: when the Concernee is in object position it is licensed by an applicative suffix (26a-b), which is absent when the Concern is in object position (26c). When the Concern is a body part of the Concernee, both mappings are possible and there is never an applicative suffix. 
(26) Orungu (Odette Ambouroue, p.c.)

a. òywán àdyúnì ònênđì̀

$\begin{array}{lll}\text { òyw-ânà } & \text { à-á-dyú-n-ì } & \text { ò-nênđì } \\ \text { 1-child.DTP } & \text { SM }_{1} \text {-PRF-die-APPL-PRF } & \text { 3-schoolmaster.DTP } \\ \text { CONCERN } & \text { CONCERNEE }\end{array}$

'The schoolmaster's child has died.'

b. nágò yítpyén ònênģì

$\begin{array}{lll}\text { nágò } & \text { í-ì-pí-èn-à } & \text { ò-nênḑì } \\ \text { 9.house.DTP } & \text { SM }_{9} \text {-PRs-burn-APPL-PRS } & \text { 3-schoolmaster } \\ \text { CONCERN } & \text { CONCERNEE }\end{array}$

'The schoolmaster's house is burning.'

c. èrêrè zápóswì ìdyâvì

$$
\begin{aligned}
& \text { è-rêrè zé-á-pósw-ì ì̀-yâßì } \\
& \text { 7-tree.DTP SM } \text { SM}_{7} \text {-PRF-fall-PRF 10b-leaf.DTP } \\
& \text { CONCERNEE CONCERN }
\end{aligned}
$$

'The tree's leaves have fallen.'

A special case of Concernee to subject mapping has sometimes been called possessor deletion (e.g. in Hyman 1977). It occurs when the Agent and Concernee roles are coreferential and jointly expressed as the subject (27-28). Since the Haya construction illustrated in (28a) is used to express a prototypical Concernee-Concern situation type, its use is obligatory. That is, an alternative wording with a first person singular possessive pronoun modifying 'hands' would be ungrammatical (28b). The joint expression of Agent and Concernee as a subject is not allowed in Chimwiini, according to Henderson (2014: 314). 
(27) Lunda (Kawasha 2003)

kánsi wakotoka mwendu

ka-ánsi wu-a-kotok-a mu-endu

12-child $\mathrm{SM}_{1}$-PST-break-FV 3-leg

CONCERN

CONCERNEE

'The child broke his leg.'

(28) Haya (Hyman 1977: 100)

a. y-k-óógy' émi-kôno

$\mathrm{SM}_{15 \mathrm{sG}}$-FPST-wash 4-hands

CONCERNEE CONCERN

'I washed my hands.'

b. y-k-óógy' émi-kóno y-ange

$\mathrm{SM}_{1 \mathrm{sG}}$-FPST-wash 4-hands 4-POSs.1SG

*'I washed my hands.'

??'I washed my (detached) hands.'

5.4. Presence of a possessive pronoun co-referential with the Concernee

In Orungu, Concernee objects are compatible with a co-referential possessive pronoun (29a), except when the Concernee is a body part (29b).

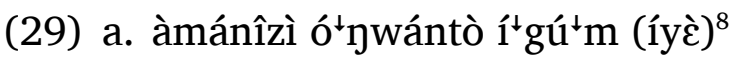

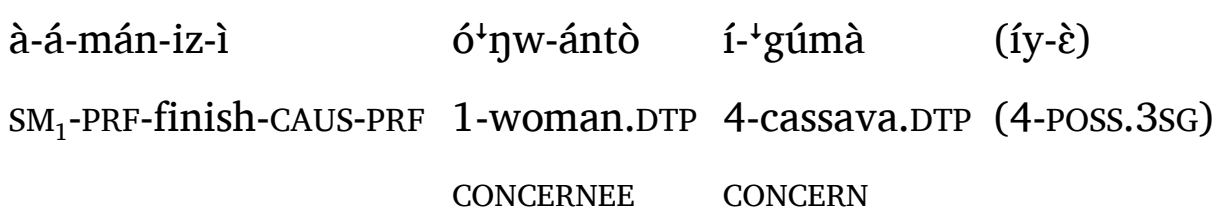

'He has finished the woman's cassava.'

\footnotetext{
${ }^{8}$ The absence of an applicative suffix on the verb 'finish' is due to maximality constraints on verb stems in Orungu. Whenever the addition of an applicative suffix would lead to a verb stem of more than three syllables, the suffix is simply left out, without consequences for the syntax. That is, an applied complement can still be used (Van de Velde \& Ambouroue 2017: 621-622). The verb stem consistes of everything from the root onward, including the Final Vowel morpheme.
} 
b. ògâygà àyìngí ójwànà ó 'gó (*wè)

$\begin{array}{lllll}\text { ò-gângà } & \text { à-à-yìng-í } & \text { òyw-ânà } & \text { ó-gò } \quad \text { (ò-è) } \\ \text { 1-healer.DTP } & \text { SM } & \\ & & & & \\ & & \text { CONCEST-treat-FPST } & \text { 1-child.DTP } & \text { 3-arm.DTP (3-POSS.3SG) } \\ & \text { CONCERN }\end{array}$

'The healer treated the child's arm.'

This possibility is rarely explicitly discussed in the Bantu literature on external possession, so it is hard to know how widespread it is. At face value, the Chimwiini example in (30) suggests that an adnominal possessor coexists with a co-referential Concernee object, but Henderson adduces syntactic and prosodic evidence for claiming that this is not acceptable in Chimwiini and that maana 'child' is in apposition to kuluu=ye 'his/her leg' in (30), rather than being a separate argument of the verb.

(30) Chimwiini (Henderson 2014: 299)

$\begin{array}{llcl}\text { Omari } & \text { vunz-ile } & \text { maana } & \text { kuluu }=\mathrm{y} \text {-e } \\ \text { Omar } & \mathrm{SM}_{1} \text {.break-PST } & \text { 1.child } & \text { 9.leg }=\text { 9-POSs.3SG } \\ & & \text { CONCERNEE } & \text { CONCERN }\end{array}$

'Omar broke the child's leg.'

\subsection{Recursivity}

Bantu languages differ according to whether they allow multiple Concernee arguments to co-occur in one clause. This too is a parameter of variation on which little information is available in published sources. Example (31) from Orungu shows two successive Concernee roles expressed as objects of the verb 'break', which does not have an applicative suffix in this example, but can optionally have one. The same example can be further expanded, e.g. to 'the door of the house of my teacher'. 
(31) Orungu (Odette Ambouroue p.c.)

áfè wádyónì myé nág ìgúgè

$\begin{array}{lllll}\text { á-fè } & \text { wá-á-dyón-ì } & \text { myé } & \text { nâgò } & \text { ì-gûgè } \\ \text { 2-burglars.DTP } & \text { SM }_{2} \text {-PRF-break-PRF } & \text { 1SG.PRO } & \text { 9.house.DTP } & \text { 5-door.DTP } \\ & & \text { CONCERNEE } & \text { CONCERN } \\ & & & \text { CONCERNEE } & \text { CONCERN }\end{array}$

'The burglars have broken the door of my house.'

In Rwanda, two Concernee objects can only co-occur in examples such as $(14 \mathrm{~b}=20)$, where one is a nuclear and the other an applied Concernee.

\section{Concernees without Concerns?}

The available descriptions of Concernee-Concern constructions in the Bantu languages do not allow for a fine-grained areal or genealogical interpretation of the facts. Nevertheless, a comparison of my data from Orungu with the published descriptions cited in the previous sections suggests that there are generally fewer restrictions on Concernee-Concern constructions in the Northwest than in the Eastern Bantu languages. Whereas in Eastern Bantu languages the family resemblance with the prototypical situation type has to be relatively strong in order for Concernee-Concern constructions to be possible, Orungu is much more permissive. An example is (26c) 'The tree's leaves have fallen', where the possessor is not human. The only resemblance with the prototypical situation type is that leaves could be thought of as a body part of a tree. Similar examples can be found in the north-western Bantu language Eton (32-33), which also appears to lack obvious restrictions on the use of Concernee-Concern constructions. The situations in (32-33) do not involve a body part and no change of state or even physical contact. The extra-thematic argument 'me' is also not clearly or necessarily affected by the situation. Its only similarity with prototypical Concernees is that it is high on the referentiality hierarchy. 
(32) Eton (Van de Velde 2008: 300)

avé mâ múná ítpágâ

à- ${ }^{\mathrm{H}}-\mathrm{v} \hat{\varepsilon}^{-\mathrm{H}} \quad$ mà $\quad \mathrm{N}$-úná ì-págà

$\mathrm{SM}_{1}$-PST-give-NF 1SG.PRO 1-child 7-present

'He gave my child a present.'

lit. 'He gave me the child a present.'

(33) ygòb í-ngâ mă 'ság

10.shoe $\mathrm{SM}_{10}$-INC 1 SG.PRO become_supple

'My shoes are becoming supple.'

lit. 'The shoes are becoming me supple.'

However, Eton and other north-western Bantu languages such as Gyeli freely allow the insertion of an extra-thematic argument that is more or less concerned by the situation, without the need for it to have a privileged relation with a thematic argument of the verb. The examples in (34) and (35) illustrate this. They are reminiscent of so-called Ethical datives in European languages. There is therefore no need for the grammarian to recognise a distinct Concernee-Concern construction in the constructicon of languages such as Eton in order to deal with examples such as (32-33).

(34) Eton (Van de Velde, in preparation)

àpám mâ kúgúlútú

à- ${ }^{\mathrm{H}}$-pám mà kúgúlútú

$\mathrm{SM}_{1}$-PST-arrive 1SG.PRO suddenly

'He arrived suddenly.'

lit. 'He arrived me suddenly.'

(35) Gyeli (Grimm, in preparation)

b-ùdì bà síléč̃ $\quad m \hat{\varepsilon} \quad$ wè ndáwò tù vâ

2-person 2.RPST finish.CMPL 1sG.PRO die 9.house inside here

'The people have all died here inside the house.'

lit. 'The people have all died me here inside the house.' 
In this respect, the north-western Bantu languages are similar to most European languages, which, according to Seržant (2016), also lack a dedicated external possession construction. The need to recognise a separate Concernee-Concern construction in the Eastern Bantu languages arises from the construction-specific reduced behavioural potential of the object role onto which the Concern is mapped, from the fact that in many languages Concernee-Concern constructions are the only ones that allow three unmarked postverbal NPs and from the fact that no Concernee role can be added in the absence of a Concern with which it has a privileged relation.

\section{Conclusions}

Analyses of external possession have been confronted with two major difficulties. The first is that of determining the preconditions for external possession. The second is that of determining what licenses the presence of the external possessor as a nuclear argument in rule based grammar models. Both can be resolved in a constructional prototype approach. At least for the Bantu languages, there is ample evidence for concluding that so-called external possession constructions are prototypically used to express the situation in which somebody is affected through an action on one of their body parts. In such situations, the affected person and the body part are both thematic participants and each is mapped onto a syntactic role defined by the construction. The existence of a prototypical situation for external possession is evidenced by three independent arguments: omnipresence, obligatoriness and lack of marking. The use of the construction to express situations that depart from the prototype is more or less negotiable, depending on the language, the speaker and the context. Prototypical categories have a highly specific and salient core that can be extended along different dimensions via family resemblances. In this respect, they differ from Aristotelian categories defined in terms of necessary and sufficient conditions. In trying to determine when external possession is possible, previously published analyses have taken an Aristotelian approach. In such an approach, the inclusion of something as specific as body parts 
among the necessary conditions for external possession seems random, which must have led to them being replaced by the more general and abstract category of inalienable possessees. However, this is descriptively inadequate. Understanding that was essential for recognising the existence of a prototypical situation.

The prototypical situation minimally involves a body part and its owner, which are construed as distinct participants. In external possession constructions these prototypical participants correspond to two thematic roles that are mapped onto unflagged syntactic relations. I call the role that corresponds to the body part the Concern and the other role the Concernee. I propose to rename external possession constructions as Concernee-Concern constructions, which has the advantage of being agnostic about whether they are really used to express linguistic possession.

Recognising the Concernee and the Concern as construction-specific roles and naming them has the further practical advantage of facilitating the formal analysis and typology of Concernee-Concern constructions. The typology in Section 5 shows that the object relation of the Concern tends to have a more restricted behavioural potential than that of the Concernee. An implicational universal that holds in my sample is that if a language has a Concernee-Concern construction with an applicative suffix on the verb, it also has one without an applicative suffix. Moreover, the prototypical Concernee-Concern situation is always expressed by means of a construction without an applicative suffix. Many properties of ConcerneeConcern constructions in the Bantu language remain to be analysed. For instance, in languages where Concernee-Concern constructions with an intransitive verb allow the Concernee to be mapped onto either the subject relation or an object relation, the conditions determining the choice between these alternative mappings have to my knowledge never been identified.

Finally, Concernee-Concern constructions are not universal in the languages of the world, nor even within the Bantoid family. On the one hand, there are languages such as the non-Narrow Bantu Bantoid language Mundabli (Voll 2017), which do not allow Concernee roles to be expressed as nuclear arguments of the verb. At the other extreme of the scale, there are languages such as the north-western Bantu language 
Eton, where an extra-thematic argument expressed as a nuclear argument of the verb can always be added, so that there may be no need to recognise a distinct Concernee-Concern construction in them.

\section{Bibliography}

Bickford, J. Albert. 1986. Possessor Ascension in Kinyarwanda. Chicago Linguistic Society, vol. 22, 129-143.

Creissels, Denis. 2006a. Syntaxe générale. Une introduction typologique (Langues et Syntaxe). Vol. 1.2 vols. Paris: Lavoisier.

Creissels, Denis. 2006b. Syntaxe générale. Une introduction typologique (Langues et Syntaxe). Vol. 2. 2 vols. Paris: Lavoisier.

Davies, William D. 1997. Relational succession in Kinyarwanda possessor ascension. Lingua 101. 89-114.

Gerdts, Donna. 1999. Mapping possessors: parameterizing the external possession construction. In Doris Payne \& Immanuel Barshi (eds.), External Possession. Amsterdam/Philadelphia: John Benjamins Publishing Company.

Grimm, Nadine. in preparation. A grammar of Gyeli.

Henderson, Brent. 2014. External possession in Chimwiini. Journal of Linguistics 50(2). 297-321.

Hinnebusch, Thomas J. \& Robert S. Kirsner. 1980. On the Inference of "Inalienable Possession" in Swahili. Journal of African Languages and Linguistics 2(1). 1-16.

Hole, Daniel. 2006. Extra argumentality - affectees, landmarks, and voice. Linguistics 44(2). 383-424.

Hyman, Larry M. 1977. The syntax of body parts. In Ernest Rugwa Byarushengo, Alessandro Duranti \& Larry M. Hyman (eds.), Haya Grammatical Structure: phonology, grammar, discourse (Southern California Occasional Papers in Linguisics 6), 99-117. Los Angeles: Department of Linguistics, University of Southern California.

Hyman, Larry M. 1996. The syntax of body parts in Haya. The Grammar of Inalienability A Typological Perspective on Body Part Terms and the Part-Whole Relation. Reprint 2011. Berlin, Boston: De Gruyter.

Kawasha, Boniface Kaumba. 2003. Lunda Grammar: A Morphosyntactic and Semantic Analysis. Eugene: University of Oregon PhD thesis. 
Kawasha, Boniface Kaumba. 2008. Relative clauses and subject inversion in Chokwe, Kaonde, Lunda and Luvale. Africana Linguistica XIV. 37-61.

Keach, Camillia N. \& Michael Rochemont. 1992. On the Syntax of Possessor Raising in Swahili. Studies in African Linguistics 23. 81-106.

Kimenyi, Alexandre. 1980. A relational grammar of Kinyarwanda. University of California Press.

Kutsch Lojenga, Constance. 2003. Bila (D32). In Derek Nurse \& Gérard Philippson (eds.), The Bantu Languages (Routledge Language Family Series 4), 450-474. London \& New York: Routledge.

Kyei-Mensah, Josephine. 1998. Inalienable possession : an aspect of the syntax of personal reference in Swahili. SOAS University of London Ph.D. http://eprints.soas.ac.uk/29101/

Nichols, Johanna \& Balthasar Bickel. 2013. Possessive Classification. In Matthew S. Dryer \& Martin Haspelmath (eds.), The World Atlas of Language Structures Online. Leipzig: Max Planck Institute for Evolutionary Anthropology. http://wals.info/chapter/59 (19 October, 2017).

Payne, Doris \& Immanuel Barshi. 1999. External Possession: What, Where, How and Why. In Doris Payne \& Immanuel Barshi (eds.), External Possession (Typological Studies in Language 39), 3-29. Amsterdam/Philadelphia: John Benjamins.

Schaefer, Ronald P. 1995. On the discourse functions of possessor movement in Emai prose narratives. In Pamela Downing \& Michael Noonan (eds.), Word Order in Discourse (Typological Studies in Language 30), 487-515. Amsterdam/Philadelphia: John Benjamins.

Schrock, Terrill B. 2007. Syntactic exorcism: toward an LFG analysis of Swahili 'external possession.' GIALens 1(3).

Scotton, Carol Myers. 1981. Extending Inalienable Possession: The Argument for an Extensive Case in Swahili. Journal of African Languages and Linguistics 3(2). 159-174. doi:10.1515/jall.1981.3.2.159.

Seržant, Ilja A. 2016. External possession and constructions that may have it. STUF Language Typology and Universals 69(1). 131-169.

Shibatani, Masayoshi. 1994. An integrational approach to possessor raising, ethical datives and adversative passives. In Susanne Gahl, Andy Dolbey \& Christopher Johnson (eds.), Proceedings of teh twentieth annual meeting of the Berkeley Linguistics Society, 461-486. Berkeley: Berkeley Linguistics Society. 
Simango, Silvester Ron. 2007. Enlarged arguments in Bantu: Evidence from Chichewa. Lingua (117). 928-949.

Taylor, John R. 2014. The mental corpus: how language is represented in the mind (Oxford Linguistics). Oxford: Oxford University Press.

Van de Velde, Mark. to appear. Adnominal possession. In Ellen Hurst, Nancy Kula, Lutz Marten \& Jochen Zeller (eds.), The Oxford Guide to the Bantu Languages. Oxford: Oxford University Press.

Van de Velde, Mark. (in preparation) Dictionnaire itón-français.

Van de Velde, Mark \& Odette Ambouroue. 2017. The origin and use of a relative clause construction that targets objects in Orungu (Bantu, Gabon). Studies in Language 41(3). 615-637.

Voeltz, Erhard F. K. 1976. Inalienable possession in Sotho. Studies in African Linguistics Supplement 6. 255-266.

Voll, Rebecca. 2017. A Grammar of Mundabli, A Bantoid (Yemne-Kimbi) language of Cameroon. Leiden: Universiteit Leiden.

Zeller, Jochen. 2012. Object marking in isiZulu. Southern African Linguistics and Applied Language Studies 30(2). 219-235. 